\title{
A NOTE ON CORPORATE ACTORS
}

I use "Texaco" (Texas Petroleum Company) as the name of the corporate entity that explored for and produced oil in the territory of the indigenous Cofán people of Dureno, Ecuador, from 1964 through 1990. The actual corporate structure, however, was more complicated. In Ecuador, Texaco worked in a consortium with Gulf Oil until 1977. In 1974, Ecuador's state oil company, whose original name was Corporación Estatal Petrolera Ecuatoriana, obtained a 25 percent share in the consortium. In 1977, Gulf transferred its share to the state company, which became the majority owner. In 1989, the state company changed its name to Petroecuador. In 2007, the state company again changed its name to Petroamazonas.

Importantly, Texaco was the main operator in the consortium's concession. As the environmental lawyer Judith Kimerling has methodically noted in a 2006 journal article, Texaco was responsible for the design, construction, and maintenance of the petroleum-related infrastructure, including the pipelines, oil wells, roads, and waste disposal system. In 1990, Texaco transferred the operator role to Petroecuador and left the country entirely in 1992. In 2001, Texaco merged with Chevron. For a short while, the company was called ChevronTexaco. Now, it is simply Chevron. 